\title{
T-Box Transcription Factor TBX22
}

National Cancer Institute

\section{Source}

National Cancer Institute. T-BoX Transcription Factor TBX22. NCI Thesaurus. Code C150338.

T-box transcription factor TBX22 (520 aa, $58 \mathrm{kDa}$ ) is encoded by the human TBX22 gene. This protein is involved in palate development and transcriptional regulation. 